\author{
SERIES 'OCCUPATIONAL ASTHMA' \\ Edited by C.E. Mapp
}

\title{
Mechanisms and pathology of occupational asthma
}

\author{
C.E. Mapp*, M. Saetta*, P. Maestrelli*, A. Di Stefano*, P. Chitano*, \\ P. Boschetto**, A. Ciaccia**, L.M. Fabbri**
}

Mechanisms and pathology of occupational asthma. C.E. Mapp, M. Saetta, P. Maestrelli, A. Di Stefano, P. Chitano, P. Boschetto, A. Ciaccia, L.M. Fabbri. CERS Journals Ltd 1994.

ABSTRACT: Since the pathogenesis and the pathological features of occupational asthma are similar to those of nonoccupational asthma, the former represents a very useful model for the investigation of the pathogenesis of asthma in general.

More than one mechanism may be operative in occupational asthma. Among the mechanisms proposed, immunological mechanisms and airway inflammation play an important role. There is evidence to confirm that T-lymphocyte activation and local accumulation in the bronchial wall of activated eosinophils occurs in asthma of diverse aetiology, i.e. immunoglobulin E (IgE)-mediated, occupational and intrinsic.

Neurogenic pathways should be further investigated as a potential mechanism of modulation and amplification of airway inflammation in occupational asthma. Eur Respir J., 1994, 7, 544-554. \author{
University of Ferrara, Italy. \\ Correspondence: C.E. Mapp \\ Istituto di Medicina del Lavoro \\ Via J. Facciolati 71 \\ 35127 Padova \\ Italy
}

* Institute of Occupational Medicine, University of Padova, Italy. **Institute of Infectious and Respiratory Diseases,

Keywords: Airway inflammation, asthma, immunity, workplace

Received: July 201993

Accepted for publication October 71993

\section{Background}

Population studies have shown that the majority of adults and children with well-documented asthma are atopic (i.e. they produce an increased amount of immunoglobulin $\mathrm{E}$ (IgE) antibodies against aeroallergens), and that the prevalence of asthma is greater in subjects with high serum IgE levels [1]. Inhaled allergens from mites present in house dust are probably the most important risk factor of asthma [2]. Asthma induced by mites is a classical example of IgE-mediated asthma, and immunochemical measurements of dust antigen have been performed. Methods for the reduction of mite allergen in the living environment have been developed, with the hope of improving the clinical aspects of the disease. Occupational asthma shares many characteristics with IgE-mediated asthma: in both, the agent responsible is known, and the clinical picture, the response to inhalation challenge in the laboratory and the response to antiasthma drugs are all similar.

Whilst occupational asthma induced by high molecular weight compounds is often mediated by an IgE mechanism, in most subjects with occupational asthma induced by low molecular weight compounds it is not possible to demonstrate an IgE-mediated mechanism. Nonatopic asthma has many features of chronic cellmediated disease which occurs independently of an IgEmediated immunological mechanism.

Since it has recently been shown that the pathological features of occupational asthma are similar to those found in nonoccupational asthma [3], the former represents a very useful model for the investigation of the patho- genesis of asthma in general (i.e. IgE-mediated, intrinsic, and occupational).

Occupational asthma offers a unique opportunity to study the natural history of the disease, since exposure to the sensitizing agent can be abolished completely, something which is not feasible in mite-induced asthma.

\section{Mechanisms}

Even if the precise causative mechanism of occupational asthma is unknown, several mechanisms have been proposed, i.e. immunological, pharmacological and genetic mechanisms, and airway and neurogenic inflammation. More than one mechanism may be operative in occupational asthma. Whether various mechanisms are involved in occupational asthma induced by different agents is also unknown.

An agent which causes asthma may be considered as "inducer" (i.e. causing reversible airway bronchoconstriction associated with long-lasting airway hyperresponsiveness to nonspecific and/or specific agents) or as "inciter" (i.e. triggering asthma attacks) [4].

Among the mechanisms proposed in the pathogenesis of occupational asthma, the immunological one plays a key role.

\section{Immunological mechanism}

Immunological mechanism does not necessarily imply an IgE-mediated immunity (fig. 1). In fact, if 
occupational asthma caused by the exposure to high molecular weight compounds is, in many cases, IgE-mediated, occupational asthma due to the exposure to low molecular weight compounds is rarely so; but, it may be considered immunologically-mediated on the basis of recent studies showing that in the bronchial mucosa of subjects with occupational asthma induced by low molecular weight compounds, activated T-lymphocytes, metachromatic cells and activated eosinophils are present [5].

Complex cellular and molecular interactions cause airway inflammation in asthma. The type of inflammatory infiltrate depends on specific events, including the nature and activities of the specific adhesion molecules expressed by the endothelium and by blood leucocytes, as well as the release of chemotactic factors, which cause migration of cells into tissue.

The immune system is divided into the antibody and cellular branches. B-cells produce and secrete specific humoral antibodies, whilst T-lymphocytes modulate B-cell function by helper and suppressor functions, participate in delayed hypersensitivity responses, and mediate several types of cellular toxicity.

In the generation of an immune response, the first step is the activation of T-cells by the recognition of antigen, which is presented on the surface of accessory cells [6-16]. The accessory cells or antigen-presenting cells (APCs) are macrophages, dendritic cells and Bcells. Dendritic cells are considered to be the major anti- gen-presenting cells (APCs) in the lung and airway wall.

T-cells recognize soluble antigens which have been processed by APCs. Antigen recognition by T-cells is mediated by the clonotypic T-cell receptor (TCR), which recognizes a specific complex of an antigenderived peptide bound to a major histocompatibility complex (MHC) molecule of class I or class II (respectively, MHC-I and MHC-II).

The accessory cells, along with the ability to process antigens, are also capable of facilitating the binding of the processed antigen to the intracytoplasmic MHC molecules, which then migrate to and are expressed on their cell surface. Finally, they elaborate and secrete interleukin-1 (IL-1), a cytokine which stimulates T-cells. The airway dendritic cells bind inhaled allergen in situ and then present it to T-cells. It has recently been demonstrated that, in the presence of an inflammatory stimulus, dendritic cells exhibit a response, by increasing in numbers in the epithelium and upregulation of surface expression of integrins.

Whereas, so-called "helper CD4+" T-cells recognize antigens bound to the class II MHC molecules, the suppressor/cytotoxic CD8+ T-cells recognize antigens in the context of class I MHC molecules. After activation by antigen, T-lymphocytes secrete a number of lymphokines, which attract, activate and promote the growth and differentiation of other leucocytes.

Based on murine studies, T-helper (Th) clones may be subdivided on the basis of their cytokine profile [17].

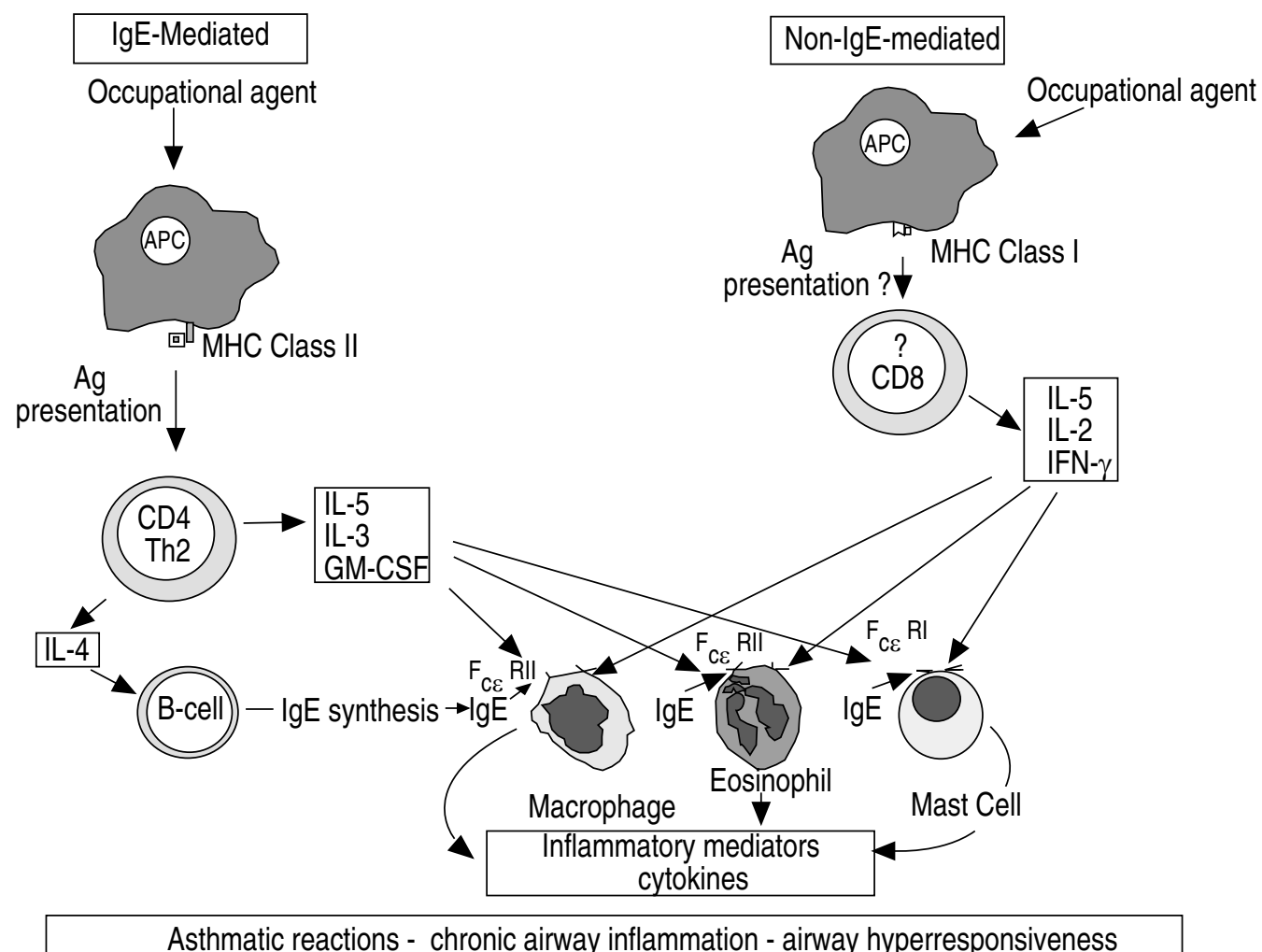

Fig. 1. - Postulated immunological mechanisms in occupational asthma. IgE: immunoglobulin E; APC: antigen presenting cell; MHC: major histocompatibility complex; Ag: antigen; Th: T-helper; IL: interleukin; GM-CSF: granulocyte-macrophage colony-stimulating factor; IFN- $\gamma$ : interferon- $\gamma$. 
The use of antigen-specific T-lymphocyte clones has confirmed the results [18]. Th1 clones produce predominantly IL-2 and interferon- $\gamma$ (IFN- $\gamma$ ), whereas Th2 clones produce mainly IL-4 and IL-5. Both Th1 and Th2 produce IL-3 and granulocyte/macrophage colonystimulating factor (GM-CSF). In vivo studies in humans have confirmed the existence of functionally distinct subsets of T-lymphocytes [19]. There is now evidence that a number of other cells produce IL-3, IL-4, IL-5, GM-CSF and other cytokines [20-22].

In addition to their role as helper cells for the production of humoral antibodies by B-cells, activated CD4+ lymphocytes may be considered as inflammatory cells. Activated T-cells secrete interleukin-8 (IL-8), which is a chemotactic cytokine for polymorphonuclear leucocytes. They are also an important source of GM-CSF and IL-5. The first is important in eosinophil development and activation [23, 24] and plays a significant role in the amplification of eosinophilic inflammation. IL-5 appears to be specific in promoting the development, adhesion [25] and activation of eosinophils, and is the predominant eosinophil-active cytokine present in bronchoalveolar lavage (BAL) fluids during allergen-induced late phase inflammation [26].

Activated T-cells may, therefore, initiate and propagate allergic inflammation in the airways and participate directly in the events responsible for asthma exacerbations [27-29]. There is now compelling evidence to confirm that T-lymphocyte activation and local accumulation in the bronchial wall of activated eosinophils occur in asthma of diverse aetiology, i.e. IgE-mediated, intrinsic and occupational [30-34].

Regarding CD8+ T-cells, different subsets participate directly in the B-cell suppressor function (CD8 $11 \mathrm{~b}$ ), whereas the CD8 and the CD28 act as cytotoxic cells for exogeneous and endogenous antigens [35]. Recently, it has been reported that soluble exogenous antigens or haptens are able to mount an MHC class I restricted response [36, 37].

Antibody-mediated immunity. Occupational agents, particularly high molecular weight compounds, act through an IgE-mediated mechanism. These compounds act as complete antigens and are, therefore, capable of crosslinking surface-bound IgE. The specific reaction which occurs between allergen and IgE produces a cascade of events, that causes the activation of inflammatory cells, and the synthesis and release of several inflammatory mediators, which mediate the inflammatory reaction in the airways $[38,39]$. Low molecular weight compounds, to produce a complete allergen, must first react with autologous or heterologous proteins.

In vivo and in vitro studies in humans may be performed to confirm the role of sensitization to occupational agents in occupational asthma. These studies include skin tests, radioallergosorbent tests (RAST) and enzyme-linked immunosorbent assay (ELISA) tests [40].

In subjects with occupational asthma induced both by high and low molecular weight compounds, specific immunoglobulins ( $\operatorname{IgE}, \operatorname{IgG})$ may be found [41-
44]. However, positive skin tests and/or specific antibodies against occupational allergens are often present in subjects both with and without symptoms of asthma, suggesting that their presence may reflect exposure rather than disease [44, 45]. These subjects require monitoring with the aim of confirming sensitization. Skin tests and specific antibodies may be helpful in the diagnosis of occupational asthma due to high molecular weight compounds. Regarding occupational asthma due to low molecular weight compounds, it has been reported that in asthma induced by diisocyanates, such as hexamethylene diisocyanate (HDI) and diphenylmethane-4'-4'diisocyanate (MDI) specific IgG antibodies are more important than IgE antibodies [43]. These antibodies are also present in some subjects with no history of asthma and a negative inhalation challenge. In anhydrideinduced asthma the role of the antibody-mediated immunity has been more clearly confirmed. Chemicals, such as tri-mellitic anhydride (TMA) or methyl tetrahydrophthalic anhydride (MTHPA) produce highly allergenic epitopes after conjugation with proteins. Specific antibodies against these chemicals correlate well with the presence of occupational asthma [46-49]. Studies of RAST cross-inhibition have shown that the antibody responses are heterogeneous, i.e. the response is against either the ligand or against new antigenic determinants with no evidence of hapten specificity. For other agents, such as platinum salts, an antibody-mediated response has also been confirmed [50-54]. High levels of both $\mathrm{IgE}$ and cutaneous reactivity may persist as long as $4 \mathrm{yrs}$ after the cessation of exposure, suggesting that platinum salts may cause polyclonal (noncognate) stimulation of IgE-producing B-cells.

As with isocyanate-induced asthma, specific antibodies against plicatic acid and against morphine have been found, respectively, in symptomatic and asymptomatic workers exposed to red cedar or to morphine [44, 55].

Under certain circumstances, the presence of specific $\operatorname{IgE}$ or $\operatorname{IgG}$ is useful in the diagnosis of occupational asthma (exposure to high molecular weight compounds and to certain low molecular weight compounds), whereas in others, their presence is a biological marker of exposure and must be associated with pulmonary function tests to detect the clinical onset of the disease.

Cell-mediated immunity. In addition to their role in IgE-mediated responses through the induction and suppression of IgE synthesis by B-lymphocytes, T-lymphocytes release cytokines, which recruit and activate other inflammatory cells. T-cells may be considered as effector cells in allergic inflammation and asthma through pathways which are distinct from B-cell regulation and $\operatorname{IgE}$ production.

Cell-mediated immunity has not been extensively investigated in occupational asthma. In isocyanateinduced asthma, activated (CD25+) CD4 T-lymphocytes, activated eosinophils and mast cells have been shown in bronchial mucosa [3, 34]. The number of CD25+ cells (IL-2-bearing cells), and of very late activation antigen (VLA)-bearing cells increases and total (MPB+) eosinophils and actively secreting EG2+ cells also 
increase [34]. These findings suggest that occupational and nonoccupational asthma have a similar inflammatory cell infiltrate, and confirm that T-lymphocyte activation and eosinophil recruitment are important in asthma of diverse aetiology.

That a T-lymphocyte-eosinophil interaction occurs in allergic inflammation and in asthma is supported by the finding of IL-5 messenger ribonucleic acid (mRNA) expression in bronchial biopsies of asthmatics [56].

In occupational asthma induced by isocyanates, we have observed an increase of CD8+ cells and eosinophils in the peripheral blood of subjects who developed a late asthmatic reaction after exposure to toluene diisocynate (TDI) in the laboratory, 48-72 $\mathrm{h}$ after the exposure to the chemical [57]. Exposure to an occupational sensitizer such as TDI, induces airway narrowing, recruitment and activation of inflammatory cells.

In subjects with nickel-induced asthma, nickel-specific T-lymphocyte clones have been isolated, suggesting that T-cell-mediated immunity is present in occupational asthma [58]. In subjects with hard metal-induced asthma, cobalt-induced lymphocyte proliferation has been shown [59]. Recently, bronchial biopsies in two subjects with occupational asthma due to TDI were performed $48 \mathrm{~h}$ after an asthmatic reaction induced by exposure to TDI in the laboratory and after 3 months free from exposure to the sensitizing agent. After inhalation challenge with TDI, the number of eosinophils and cells expressing IL2 receptor increased in the bronchial mucosa. Fragments of bronchial biopsies were cultured in the presence of IL-2 in order to expand activated T-cells in the tissue, and T-blasts were cloned [60,61]. From the $48 \mathrm{~h}$ specimens, the majority of clones exhibited the CD8 phenotype. All CD8 clones produced IFN- $\gamma, 44 \%$ produced IL-5 but only $6 \%$ secreted IL-4. In biopsies taken 3 months after the cessation of exposure, the number of mucosal eosinophils and CD25+ was in the range of normality, and IL-2 stimulation did not promote growth of T-cells. These findings support a role for IL-5 producing CD8+ T-cells in occupational asthma induced by isocyanates.

\section{Airway inflammation}

Active asthma is characterized by the presence of airway inflammation [62]. Airway inflammation may be assessed indirectly by using inhalation challenge studies [63], by studies on the role of anti-inflammatory drugs, mainly steroids, on asthma [64], and directly by using fibreoptic bronchoscopy in order to perform bronchoalveolar lavage (BAL) and to obtain bronchial biopsies. These two techniques demonstrate the presence of inflammation in the airways of asthmatics and have improved our knowledge of the inflammatory process.

\section{Bronchoalveolar lavage}

BAL fluid can be analysed for total and differential cell counts, evaluation of cell activation, and measure- ment of biochemical parameters in cell-free supernatant. This technique has also been used in asthma [65-69], and guidelines for a safe use of BAL in asthma have recently been published [70-72].

In subjects with occupational asthma, BAL fluid obtained between attacks and after cessation of exposure shows a mild change or no change at all in the total count or distribution of inflammatory cells [65]. With this technique increased numbers of inflammatory cells have been found in subjects who do not recover after the cessation of exposure [66], and during asthma attacks [67-69].

BAL obtained during late asthmatic reactions induced by occupational sensitizers shows a significant increase of inflammatory cells, i.e. neutrophils and eosinophils. An increase in albumin concentration in BAL fluid is also present in occupational asthma [73]. During early asthmatic reactions induced by occupational agents, histamine, leukotrienes and other mediators are measurable in BAL fluid [74]. After challenge with isocyanates, leukotriene $\mathrm{B}_{4}$ levels are increased, which may be responsible for leucocyte infiltration in the airways [75]. Macrophages, epithelial cells or neutrophils may be the source of this mediator.

In the supernatant of BAL fluid obtained during late asthmatic reactions, the concentration of albumin is increased compared to findings obtained from controls or during an early asthmatic reaction [73]. It has been suggested that this may reflect microvascular leakage and mucosal oedema [76]. Macromolecules of albumin leak between the gaps of endothelial cells in the postcapillary venule. They cross two membranes, the endothelial and the epithelial basement membrane and accumulate in the airway lumen. The process of plasma exudation is associated with movement of water, which causes mucosal oedema and accumulation of exudate in the airway lumen. It has recently been proposed that the plasma exudation process is not necessarily associated with airway oedema, epithelial disruption, or increased mucosal absorption [77]. The author suggests that plasma exudates, by increasing the hydrostatic pressure in the subepithelial space, create pathways for their luminal entry. If transient oedema is induced by airway plasma exudation, it is unlikely to compromise the airway functions. When the exudative response is massive and prolonged, it is possible that the physical alterations of the wall and the lumen are harmful to the airways [78, 79].

In a sensitized subject who died suddenly after occupational re-exposure to isocyanates, we observed airway oedema and exudate in the airway lumen [80].

Fibreoptic bronchoscopy has also been used to obtain bronchial biopsies, and to clarify the pathological features of occupational asthma.

\section{Bronchial biopsies}

Occupational asthma may be fatal. In a sensitized subject who died in the workplace after re-exposure to isocyanates, histological examination of the airways 
showed denudation of airway epithelium and thickening of the basement membrane, with infiltration of the lamina propria by leucocytes, mainly eosinophils, and diffuse mucous plugging of bronchioles. Bronchial smooth muscle appeared hyperplastic and disarrayed, and lung parenchyma showed focal areas of alveolar destruction adjacent to areas of intact alveolar walls. It is likely that a bronchial wall thickened by persistent oedema or by an increased amount of subepithelial collagen may increase the degree of bronchoconstriction induced by a similar degree of smooth muscle shortening [81].

In bronchial biopsies obtained in subjects with occupational asthma induced by TDI, inflammatory cells are present and they compartmentalize in the airway mucosa. Whereas, eosinophils are increased in the epithelium, in the most superficial layer of the submucosa and in the total submucosa, CD45+ cells (mononuclear cells accounted for most of the CD45+ cells) are significantly increased only in the epithelium and in the most superficial layer of the submucosa, and mast cells are increased only in the epithelium. Epithelial integrity constitutes a mean of 33 and $34 \%$ coverage of the basement membrane in asthmatics and controls, respectively, and the difference is not significant. The intercellular spaces between columnar cells are similar in the two groups, but intercellular spaces between basal cells are wider in asthmatics.

Destruction or denudation of airway epithelium is considered to be a common morphological feature associated with the pathogenesis of asthma. Indeed, epithelium is not only the primary barrier protecting the underlying tissues from inhaled irritants and noxious stimuli, but it is also a metabolically active tissue [82]. It may generate mediators, such as 8,15-hydroxyeicosatetraenoic acid (HETE), an epithelial cell-derived relaxant factor, etc. Desquamation of the epithelium exposes afferent nerve endings, that are stimulated to release tachykinins, such as substance $\mathrm{P}$, which is a potent constrictor agent. The epithelial cell is an important source of cytokines

a)

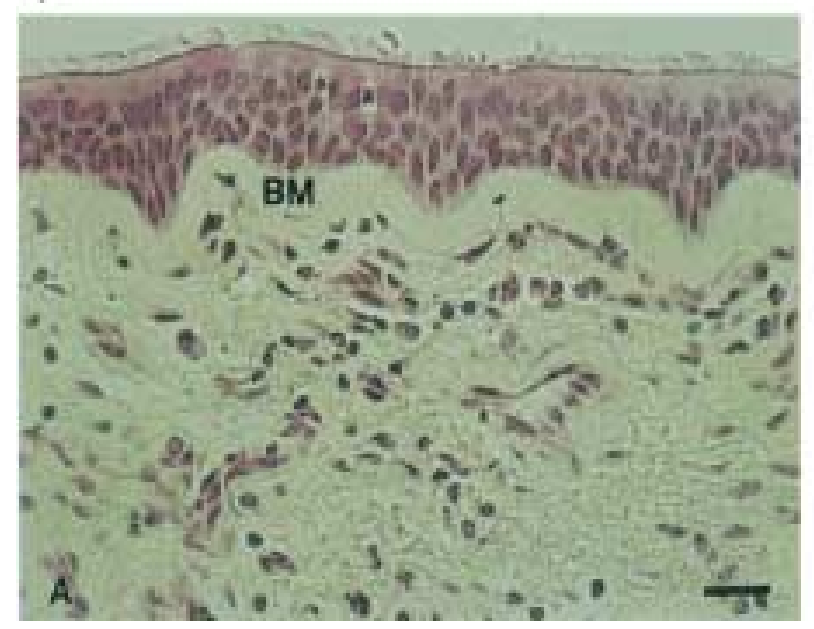

during airway inflammation, which could play different roles in the pathogenesis of asthma. The epithelial cell may be activated by inflammatory mediators. The result is an enhanced production of mediators and cytokines, which affect airway tone and may regulate the function of both resident and influxing inflammatory cells.

Returning to our findings, if we remember that the attachment of most of the columnar cells to basement membrane is mediated through basal cells, the finding of wider spaces between basal cells should induce an impairment of the adhesion of columnar cells to the basement membrane, contributing together with the influx into epithelium of inflammatory cells, to the induction of epithelial fragility, as has been observed in nonoccupational asthma [83]. Asthmatics exhibit a thicker subepithelial reticular layer of the basement membrane, whereas the true basement membrane is similar in asthmatics and controls. An increase in the thickness of the reticular layer of the basement membrane is considered to be a characteristic of asthma [84]. This finding is a histopathological feature of asthma, since in subjects affected by chronic bronchitis, a disease which causes airway inflammation and activation of T-lymphocytes, as does asthma, the thickness of the basement membrane does not differ from controls [85]. Whereas collagen IV is one of the components of the true basement membrane, collagens I, III and V produced by myofibroblasts are components of the reticular layer of the basement membrane. Since a thickened reticular layer of the basement membrane has also been described in young asthmatics with mild asthma [86], it is likely that this histological feature represents an early change of the disease.

Cessation of exposure (6 months) to an occupational sensitizer induces a change in the thickness of the basement membrane [87]. In subjects sensitized to isocyanates and removed from exposure, the thickness of the reticular layer of the basement membrane is reduced compared to that at diagnosis (fig. 2), but the inflammatory cell infiltrate is still present. After a longer time

b)

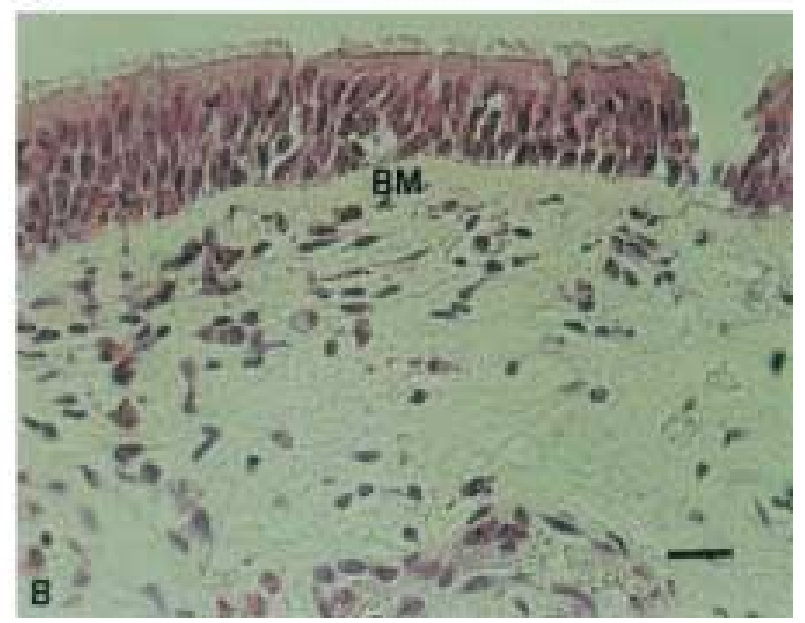

Fig. 2. - Bronchial mucosa biopsy from a subject with toluene diisocyanate-induced asthma: at diagnosis A), where a thickened reticular layer of the basement membrane (BM) and an inflammatory cell infiltrate are evident: and 6 months after cessation of exposure to the occupational agent, (B), where BM thickness is reduced, but the inflammatory cell infiltrate is still present. Stain: Haemotoxylin-eosin, light microscopy. Bars $=20$ $\mu \mathrm{m}$. 
without exposure to the sensitizing agent (6-21 months), the subepithelial fibrosis, the number of mast cells and fibroblasts, and the sensitivity to TDI are significantly reduced, whilst eosinophils, mononuclear cells and airway responsiveness to methacholine do not change [88]. The association between the thickness of the basement membrane (reticular layer) and the number of mast cells and fibroblasts, suggests a role for resident cells in the development of subepithelial fibrosis in occupational asthma.

Subjects who develop occupational asthma after a short period of exposure to TDI ( 2 yrs) have more mast cells in airway mucosa than subjects who develop respiratory symptoms after a long period of exposure to TDI (22 yrs) (fig. 3) [89]. This finding could be a "predisposing factor" for a rapid onset of the disease, or the effect of different levels of exposure to the sensitizing agent.

Airway inflammation assessed with bronchial biopsies performed at variable periods of time from the occupational exposure has been reported in isocyanateinduced asthma [66].

In subjects with occupational asthma induced by exposure to Western red cedar antigen (WRCA), it has recently been shown that the number of eosinophils is increased in BAL fluid as in atopic asthma [90]. Biopsies were obtained and in both asthmatic groups, as compared to controls, T-cells were increased; an increase

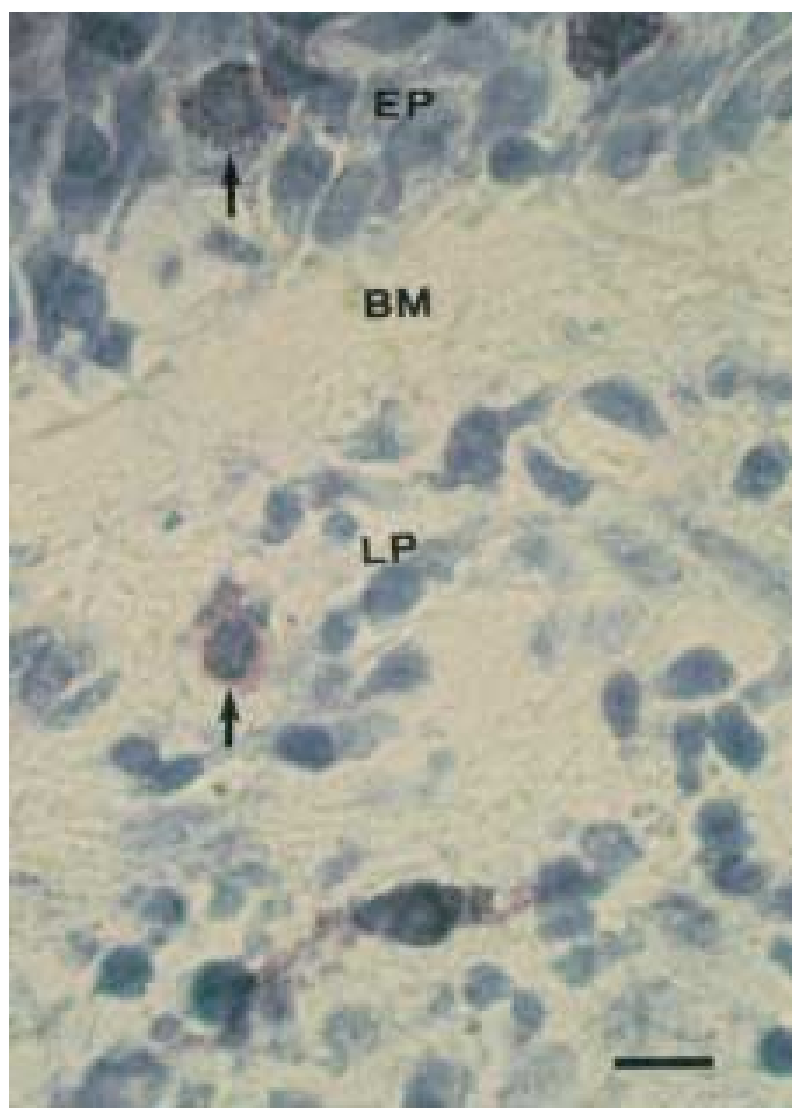

Fig. 3. - Mast cells (arrows) in epithelium and lamina propria of a subject sensitized to toluene diissocyanate, who developed asthma symptoms after a short period of exposure ( $2.5 \mathrm{yrs})$ after formaldehyde/ glutaraldehyde fixation. EP: epithelium; LP: lamina propria; BM: basement membrane. Stain: toluideine blue, $\mathrm{pH} 3$, light microscopy. $\operatorname{Bar}=12 \mu \mathrm{m}$. due mainly to CD4+ cells. Absolute numbers of CD25+ cells and activated eosinophils are increased in WRCA, confirming that in occupational asthma, as in IgE-mediated asthma, T-lymphocyte activation and eosinophil infiltration are common findings.

\section{Genetic mechanism}

In trying to resolve the genetic basis of various diseases, including asthma, two basic approaches have been used, namely "forward" and "reverse genetic mapping". The former focuses on prospective candidate genes, and in the case of asthma, genes encoding cytokines and adhesion molecules might be targeted. By using the second approach, now termed "positional cloning", the aim is to establish a linkage between the asthma phenotype and a series of highly polymorphic genetic markers.

Two studies have provided evidence for recessive inheritance of a single major gene determining high $\operatorname{IgE}$ levels [91, 92]. However, few families are incompatible with simple recessive inheritance of high $\operatorname{IgE}$ responsiveness, and further studies are needed. Specific immune responsiveness to human leucocyte antigen (HLA) class II molecules encoded by well-defined major histocompatibility complex (MHC) genes on human chromosome $6 \mathrm{p}$, are required for the presentation of an antigen to a T-cell receptor (TCR) in order to initiate the chain of events which leads to an antibody response, including $\operatorname{IgE}$.

Individual differences in HLA class II molecules may alter the ability of the molecules to bind peptides and, thereby, change the nature of T-cell recognition. There is now compelling evidence to suggest that antigens derived from extracellular sources are recognized in the context of HLA class II molecules by CD4+ T-cells. It is likely that the expression of genetic factors, regulating both overall and specific responsiveness toward specific allergenic epitopes, is affected by the intensity and frequency of the allergenic exposure, as well as by the ability of the allergen to enter the lung [93].

Recently, it has been proposed that specific HLA class II alleles could be involved in susceptibility or resistance to isocyanate-induced asthma [94], suggesting that the basic molecular and cellular mechanisms of occupational asthma induced by low molecular weight compounds are immunological, as in IgE-mediated asthma, in which the association with HLA class II genes is well-documented [95-97]. Occupational asthma induced by isocyanates and IgE-mediated asthma differ in terms of their association with particular HLA class II alleles or haplotypes. Whereas, in IgEmediated asthma, a strong positive association with haplotype DR4 is found, in isocyanate-induced asthma the frequency of haplotype DR4 is low and does not differ from controls. This finding confirms recent observations, showing a significant decrease of haplotype DR4 frequency in subjects with sensitization to mountain cedar [98]. It is interesting to note, that in both cases, the causal agents are small molecular weight compounds (isocyanate or plicatic acid). 
The exact nature of the antigen related to sensitization to isocyanates is unknown. Isocyanates themselves may be involved in antibody binding or in the induction of structural changes in an unidentified protein. It has been proposed that the mechanism of low responsiveness to foreign antigens is linked to DQ alleles, whereas DR haplotypes are implicated in the upregulation of the immune response [95]. Low responsiveness could be mediated by specific CD4+ T-cells, which in turn might activate CD8+ suppressor cells. BIGNON et al. [94] reported that allelic variations at the same locus could be associated either with resistance or with susceptibility in isocyanate-induced asthma, as occurs in autoimmune disorders where associations between the disease and allelic variations in the HLA region have been described.

By using the positional cloning approach, it is possible to map other major genes which may play a role in the expression of asthma. Moreover, the significant advances achieved in DNA technology represent an opportunity to clarify the genetics of asthma.

\section{Pharmacologic mechanisms}

Exposure to organophosphates, inhibitors of acetylcholinesterease, causes immediate symptoms of asthma. It has also been suggested that some agents, such as isocyanates and plicatic acid, act through a pharmacological mechanism. Isocyanates may act as beta ${ }_{2}$-adrenergic blocking agents [99], and plicatic acid is able to activate complement [100]. The clinical relevance of pharmacological mechanisms in occupational asthma is unclear, since these mechanisms alone cannot explain why only a minority of the exposed subjects develop asthma. It is likely that the pharmacological properties of some of the agents in the work environment interact and potentiate the immunological response.

\section{Neurogenic inflammation}

In addition to the cholinergic and adrenergic mechanisms, nonadrenergic noncholinergic (NANC), neural pathways involving the sensory nerves have been shown in human airways [101]. This network of unmyelinated sensory nerves contains potent peptides, including substance $\mathrm{P}$, neurokinin $\mathrm{A}$ and a calcitonin gene-related peptide. These neuropeptides may play a role in the development of airway inflammation. Dusts, chemicals and other irritants stimulate the sensory nerves to release substance $\mathrm{P}$ and related neuropeptides.

A recent study has shown that asthmatic airways of subjects with severe asthma do not contain vasoactive intestinal peptide (VIP) in bronchial mucosa, unlike controls [102]. The absence of this peptide, which is known to relax airways, could amplify the effects of constrictor agents. A study by the same group [103] showed that there is also an increase in both the number and the length of substance $\mathrm{P}$ immunoreactive nerve fibres in airways of subjects with asthma, when compared with airways of subjects without asthma.
Tachykinins (TK) have the ability to affect multiple cells in the airways and to cause many responses, including cough, mucus secretion, smooth muscle contraction, plasma extravasation, and neutrophil adhesion. These effects are termed "neurogenic inflammation". A neurogenic tachykinin-mediated inflammatory exudation occurs in rodent but not in human airways [104].

There is evidence that the nervous system is involved in the regulation of immune responses [105]. Mast cells and nerves may be found in close apposition, and this association has important biological significance. Both mast cells and other effector cells in the airways may be directly and indirectly regulated in their action by neuropeptides.

Neutral endopeptidase (NEP) is an enzyme present on the surface of all lung cells that contain receptors for these neuropeptides [106]. This enzyme limits the concentration of neuropeptide reaching the receptor on the cell surface by cleaving and, thus, inactivating the neuropeptides. Neurogenic inflammatory responses are presumably protective in nature. When NEP is inhibited by NEP inhibitors or by exposure to cigarette smoke, respiratory viral infections or inhalation of chemicals, such as toluene diisocyanate, neurogenic inflammatory responses are exaggerated. In the epithelium, NEP is concentrated in basal cells, which are in close association with sensory nerves profiles, suggesting an important role of basal cells in modulating neurogenic inflammatory responses by cleaving neuropeptides near their site of release. Since NEP inhibitors still potentiate the bronchomotor effects of tachykinins after removal of the airway epithelium, it is likely that NEP modulates neurogenic inflammatory responses both at the sites of neuropeptide release and at those of neuropeptide action.

TDI activates the efferent function of capsaicinsensitive primary afferents (CSPA) [107-109]. It also inhibits neutral endopeptidase in experimental animals and in vitro preparations $[110,111]$. The activation of sensory nerves is likely to be indirect, through the release of prostanoids $[112,113]$. Mast cells play a role

Table 1. - Agents which act on capsaicin-sensitive primary afferents (CSPA)

\section{Natural principles derived from plants}

Capsaicin, resiniferatoxin, piperine, eugenol, curcumin, mustard oil

\section{Mediators of inflammation and transmitters}

Bradykinin, arachidonic acid metabolites, serotonin, histamine, acetylcholine, platelet-activating factor, neurotensin, cholecystokinin octapeptide, gammaaminobutyric acid (GABA)

\section{Environmental agents}

Vapour phase of smoke, toluene diisocyanate, toluene diamina, formalin, ether, xylene, chloroacetophenone, acrylamide, allergens, bacterial chemotactic peptide

\section{Others}

Mechanical stimuli, antidromic electrical stimulation, ischaemia, $\mathrm{H}^{+}$, high potassium, prostacyclin, compound $48 / 80$. 
in the contraction induced by TDI in guinea-pig airways. Compound 48/80, an agent which degranulates mast cells, inhibits TDI-induced contraction through the release of mediators other than histamine and through a direct effect on sensory nerves [114].

Occupational stimuli (table 1), which act on CSPA and/or inhibit neutral endopeptidase, could trigger neurogenic inflammation and precipitate asthma. Neurogenic pathways should be further investigated as a potential mechanism of modulating and amplifying airway inflammation in occupational asthma.

Acknowledgments: Supported by the National Research Council (FATMA 93.00650 PF41 and Bilateral Project USA-Italy 93.00329. CT04), the CNR-ENEL ProjectInteractions of Energy Systems with Human Health and Environment-Roma, the MVRST (40\% and 60\%), the Regione Veneto, and the European Community for Coal and Steel. The authors thank P. Bortolami and L. Zedda for technical assistance, C. Howarth for editing the manuscript.

\section{References}

1. Burrows B, Martinez FD, Halonen M, et al. Association of asthma with serum IgE levels and skin-test reactivity to allergens. N Engl J Med 1989; 320: 271-277.

2. Sporik R, Holgate ST, Platts-Mills TAE, Cogsewell JJ. Exposure to house-dust mite allergen (Der $\mathrm{pI}$ ) and the development of asthma in childhood. $N$ Engl J Med 1990; 323: 502-507.

3. Saetta M, Di Stefano A, Maestrelli P, et al. Airway mucosal inflammation in occupational asthma induced by toluene diisocyanate, Am Rev Respir Dis 1992; 145: 160-168.

4. Dolovich J, Hargreave FE. The asthma syndrome: inciters, inducers and host characteristics. Thorax 1981; 36: 641-643.

5. Fabbri LM, Ciaccia A, Maestrelli P, Saetta M, Mapp CE. Pathophysiology of occupational asthma. In: Bernstein IL, Chan-Yeung M, Malo JL, Bernstein DI, eds. Asthma in the Workplace. New York, Dekker, 1993; pp. 61-92.

6. Grey HM, Sette A, Buus S. How T-cells recognize antigen. Sci Am 1989; 261: 56-64.

7. Toews GB. Pulmonary dendritic cells: sentinels of lung associated lymphoid tissue. Am J Respir Cell Mol Biol 1991; 4: 204-205.

8. Rossi GA, Sacco O, Balbi B, et al. Human ciliated bronchial epithelial cells: expression of the HLA-DR antigen and of the HLA-DR gene, modulation of the HLA-DR antigens by gamma-interferon and antigenpresenting function in the mixed leukocyte reaction. $A m$ J Respir Cell Mol Biol 1990; 3: 431-439.

9. Holt PG. Regulation on T-cell responses to inhalant allergens. Allergen Clin Immunol News 1991; 3/5: 154-156.

10. Harding CV. Cellular and molecular aspects of antigen processing and the function of class II MHC molecules. Am J Respir Cell Mol Biol 1993; 8: 461-467.

11. Harding CV, Unanue ER. Quantitation of peptide class II MHC complexes generated in antigen-presenting cells and necessary for T-cell stimulation. Nature 1990; 346: 574-576.

12. Matsui K, Boniface JJ, Reay PA, et al. Low affinity interaction of peptide-MHC complexes with T-cell receptors. Science 1991; 254: 1788-1792.
13. Dang LH, Michaleck MT, Takei B, Benacerraf B, Rock KL. Role of ICAM-1 in antigen present ation demonstrated by ICAM-1 defective mutants. J Immunol 1991; 144: 4082-4091.

14. Harding CV, Unanue ER. Modulation of antigen presentation and peptide-MHC-specific, LFA-1-dependent T-cell-macrophage adhesion. J Immunol 1991; 147: 767-773.

15. Holt PG, Schon-Hegrad MA, Oliver JJ. MHC class II antigen-bearing dendritic cells in pulmonary tissues of the rat: regulation of antigen presentation activity by endogenous macrophage populations. J Exp Med 1988; 167: 262-274.

16. Schon-Hegrad MA, Oliver J, McMenamin PG, Holt PG. Studies on the density, distribution and surface phenotype of intraepithelial class II MHC antigen (Ia)-bearing dendritic cells (DC) in the conducting airways. J Exp Med 1991; 173: 1345-1356.

17. Mosmann TR, Cherwinski H, Bond MW, Giedlin MA, Coffman RL. Two types of murine helper T-cell clone. I. Definition according to profiles of lymphokine activities and secreted proteins. J Immunol 1986; 136: 2348-2357.

18. Maestrelli P, O'Heir RE, Tsai JJ, et al. Antigen-induced neutrophil chemotactic factor derived from cloned human T-lymphocytes. Immunology 1988; 65: 605-609.

19. Wierenga EA, Snoek M, de Groot C, et al. Evidence for compartmentalisation of functional subsets of CD4+ lymphocytes in atopic subjects. J Immunol 1990; 144: 4651-4656.

20. Plaut M, Pierce JH, Watson CJ, et al. Mast cell lines produce lymphokines in response to cross-linkage of Fce-R1 or to calcium ionophores. Nature 1989; 329: 64-67.

21. Wodnar-Filipowicz A, Heusser CH, Moroni C. Production of the haematopietic growth factors GM-CSF and interleukin-3 by mast cells in response to IgE receptormediated activation. Nature 1989; 339: 150-154.

22. Bradding $\mathrm{P}$, Feather $\mathrm{IH}$, Howarth $\mathrm{PH}$, et al. Interleukin4 is localised to and released by human mast cells. $J$ Exp Med 1992; 176: 1381-1386.

23. Owen WF Jr, Rothenberg ME, Silberstein DS, et al. Regulation of human eosinophil viability, density and function by granulocyte/macrophage colony-stimulating factor in the presence of $3 \mathrm{~T} 3$ fibroblasts. J Exp Med 1987; 166: 129-141.

24. Walsh GM, Hartnell A, Waerdlaw AJ, Kurihara K, Sanderson CJ, Kay AB. IL-5 enhances the in vitro adhesion of human eosinophils, but not neutrophils in a leucocyte intergrin (CD11./18)-dependent manner. Immunology 1990; 71: 258-263.

25. Lopez AF, Sanderson CJ, Gamble JR, Campbell HD, Young IG, Vadas MA. Recombinant human interleukin-5 is a selective activator of human eosinophil function. $J$ Exp Med 1988; 167: 219-224.

26. Kita O, Weiler D, Sur S, et al. IL-5 is the predominant eosinophil-active cytokine in the antigeninduced pulmonary late-phase reaction. Am Rev Respir Dis 1993; 147: 901-907.

27. Kay AB, Corrigan CJ, Frew AJ. The role of cellular immunology in asthma. Eur Respir J 1991; 4 (Suppl. 3): 105-122.

28. Corrigan CJ, Kay AB. CD4+ T-lymphocyte activation in acute severe asthma. Relationship to disease severity and atopic status. Am Rev Respir Dis 1990; 141: 970-977.

29. Robinson DS, Hamid Q, Sun Ying, Bentley AM, et al. Prednisone treatment in bronchial asthma. Clinical 
improvement is accompanied by reduction in bronchoalveolar lavage eosinophilia and modulation of IL-4, IL-5 and IFN-gamma cytokine gene expression. Am Rev Respir Dis 1993; 148: 401-406.

30. Corrigan CJ, Haczku A, Gemou-Engesaeth V, et al. CD4 T-lymphocyte activation in asthma is accompanied by increased serum concentration of interleukin-5. Effect of glucorticoid therapy. Am Rev Respir Dis 1993; 147: 540-547.

31. Azzawi M, Bradley B, Jeffery PK, et al. Identification of activated T-lymphocytes and eosinophils in bronchial biopsies in stable atopic asthma. Am Rev Respir Dis 1990; 142: 1407-1413.

32. Bradley BL, Azzawi M, Jacobson M, et al. Eosinophils, T-lymphocytes, mast cells, neutrophils and macrophages in bronchial biopsy specimens from atopic subjects with asthma: comparison with biopsy specimens from atopic subjects without asthma and normal control subjects, and relationship to bronchial hyperresponsiveness. J Allergy Clin Immunol 1991; 88: 661-674.

33. Bentley AM, Menz G, Storz Chr, et al. Identification of T-lymphocytes, macrophages and activated eosinophils in the bronchial mucosa in intrinsic asthma: relationship to symptoms and bronchial responsiveness. Am Rev Respir Dis 1992; 146: 500-506.

34. Bentley AM, Maestrelli P, Saetta M, et al. Activated Tlymphocytes and eosinophils in the bronchial mucosa in isocyanate-induced asthma. J Allergy Clin Immunol 1992; 89: 821-829.

35. Abbas AK, Lichtman AH, Pober JS. In: Cellular and molecular Immunology. Saunders Co., 1991.

36. Walker PR, Fellowes R, Hecht EM, Lehner T. Characterization of streptococcal antigen-specific $\mathrm{CD} 8+$, MHC class I-restricted T-cell clones that down-regulate in vitro antibody synthesis. J Immunol 1991; 147: 3370-3380.

37. Kalish RS, Morimoto C. Urushiol (poison ivy) triggered suppression T-cell clone generated from peripheral blood. J Clin Invest 1988; 82: 825-832.

38. Holgate S. Mediator and cytokine mechanisms in asthma. Thorax 1993; 48: 103-109.

39. Galli SJ. New concepts about the mast cells. N Engl J Med 1993; 328: 257-265.

40. Novey HS, Bernstein IL, Mihalas LS, Terr AI, Yunginger JW. Guidelines for the clinical evaluation of occupational asthma due to high molecular weight (HMW) allergens. J Allergy Clin Immunol 1989; 84: 829-833.

41. Maccia CA, Bernstein IL, Emmett EA, Brooks SM. In vitro demonstration of the specific IgE in phthalic anhydride hypersensitivity. Am Rev Respir Dis 1976; 113: 701-704.

42. Biagini RE, Bernstein IL, Gallagher JS, et al. The diversity of reaginic immune responses to platinum and palladium metallic salts. J Allergy Clin Immunol 1985; 76 : 794-802.

43. Cartier A, Grammer L, Malo JL, et al. Specific serum antibodies against isocyanates: association with occupational asthma. J Allergy Clin Immunol 1989; 8: 507-514.

44. Tse KS, Chan H, Chan-Yeung M. Specific IgE antibodies in workers with occupational asthma due to Western red cedar. Clin Allergy 1982; 12: 249-258.

45. Frew AJ, Chan H, Dryden P, et al. Immunological studies of the mechanisms of occupational asthma due to Western red cedar. J Allergy Clin Immunol 1993; 92: 466-478.

46. Jielsen J, Welinder H, Skerfving S. Allergic airway dis- ease caused by methyltetrahydrophthalic anhydride in epoxy resin. Scand J Work Environ Health 1989; 15: 154-155.

47. Zeiss CR, Wolkonsky P, Pruzansky JJ, et al. Clinical and immunologic evaluation of trimellitic anhydride workers in multiple industrial settings. J Allergy Clin Immunol 1982; 70: 15-18.

48. Bernstein DI, Gallagher JS, D'Souza L, et al. Heterogeneity of specific IgE responses in workers sensitized to acid anhydride compounds. J Allergy Clin Immunol 1984; 74: 794-801.

49. Venables KM, Topping MD, Nunn AJ, et al. Immunologic and functional consequences of chemical (tetrachlorophthalic anhydride)-induced asthma after four years of avoidance of exposure. J Allergy Clin Immunol 1987; 80: 212-218.

50. Cleare MJ, Hughes EI, Jacoby B, et al. Immediate (Type I) allergic responses to platinum compounds. Clin Allergy 1976; 6: 183-195.

51. Murdock RD, Pepys J, Parish W, Hughes EG. IgE antibody responses to platinum group metals: a large scale refinery survey. Br J Ind Med 1986; 143: 37-43.

52. Pepys J, Parish WE, Cromwell O, et al. Passive transfer in man and the monkey of type I allergy due to heat labile and heat stable antibody to complex salts of platinum. Clin Allergy 1979; 9: 99-108.

53. Baker OB, Gann PH, Brooks SM, et al. Cross- sectional study of platinum salts sensitization among precious metals refinery workers. Am J Ind Med 1990;18: 653-664.

54. Biagini RE, Bernstein IL, Gallagher JS, et al. The diversity of reaginic immune responses to platinum and palladium metallic salts. J Allergy Clin Immunol 1985; 76: 794-802.

55. Biagini RE, Klincewicz SL, Henninsen GM, et al. Antibodies to morphine in workers exposed to opiates at a narcotics manufacturing facility and evidence for similar antibodies in heroin abusers. Life Sci 1990; 47(10): 897-908.

56. Hamid Q, Azzawi M, Ying S, et al. Expression of mRNA for interleukin-5 in mucosal bronchial biopsies from asthma. J Clin Invest 1991; 87: 1541-1546.

57. Finotto S, Fabbri LM, Rado V, Mapp CE, Maestrelli P. Increase in numbers of CD8 positive lymphocytes and eosinophils in peripheral blood of subjects with late asthmatic reactions induced by toluene diisocyanate. $\mathrm{BrJ}$ Ind Med 1991; 48: 116-121.

58. Herzog CH, Villiger B, Braun P. Nickel-specific T-cell clones in asthma: preferential use of V-beta 14 in T-cell receptor beta chain. Eur Respir J 1991; (Suppl. 14): $425 \mathrm{~s}$.

59. Kusaka Y, Nakano Y, Shirakawa T, Morimoto K. Lymphocyte transformation with cobalt in hard metal asthma. Ind Health 1989; 27: 155-163.

60. Maestrelli O, Del Prete GF, De Carli M, et al. Activated CD8 T-lymphocytes producing interferon-gamma and interleukin-5 in bronchial mucosa of subjects sensitized to toluene diisocyanante (TDI). J Allergy Clin Immunol 1993; 91: 220.

61. Del Prete GF, De Carli M, Maestrelli P, et al. Allergen exposure induces the activation of allergen-specific $\mathrm{Th} 2$ cells in the airway mucosa of patients with allergic respiratory disorders. Eur J Immunol 1993; 23: 1445-1449.

62. Editorial. Bronchial inflammation and asthma treatment. Lancet 1991; 337: 82-83.

63. Mapp CE. Occupational asthma. In: P. Vermeire, M. Demedts, JC, Yernault, eds. Progress in Asthma and COPD. Elsevier Science Publ., 1989: pp. 49-57.

64. Mapp CE, Boschetto P, Dal Vecchio L, et al. Protective effect of anti-asthma drugs on late asthmatic 
reactions and increased airway responsiveness induced by toluene diisocyanate in sensitized subjects. Am Rev Respir Dis 1987; 136: 1403-1407.

65. Chan-Yeung M, Leriche J, McLean L, Lam S. Comparison of cellular and protein changes in bronchial lavage fluid of symptomatic and asymptomatic patients with red cedar asthma on follow-up examination. Clin Allergy 1988; 18: 359-365.

66. Paggiaro PL, Paoletti P, Bacci E, et al. Eosinophils in bronchoalveolar lavage (BAL) of patients with toluene diisocyanate (TDI) asthma after cessation of work. Chest 1990; 98: 536-542.

67. Fabbri LM, Boschetto P, Zocca E, et al. Bronchoalveolar neutrophils during late asthmatic reactions induced by toluene diisocyanate (TDI). Am Rev Respir Dis 1987; 136: 36-42.

68. Lam S, LeRiche J, Phillips D, Chan-Yeung M. Cellular and protein changes in bronchoalveolar lavage fluid after late asthmatic reactions in patients with red cedar asthma. J Allergy Clin Immunol 1987; 80: 44-50.

69. De Monchy GR, Kauffman HF, Venge P, et al. Bronchoalveolar eosinophilia following allergen-induced late-phase asthmatic reactions. Am Rev Respir Dis 1985; 131: 373-376.

70. Fabbri LM, DeRose V, Godrad PH, Boschetto P, Rossi GA. Guidelines for bronchoalveolar lavage in asthma. Eur Respir Rev 1992; 2: 116-123.

71. Kleck K, Pohl W, (eds). Technical recommendations and guidelines for bronchoalveolar lavage (BAL). Eur Respir J 1989; 2: 561-585.

72. Workshop summary and guidelines. Investigative use of bronchoscopy, lavage and biopsies in asthma and other airway diseases. Eur Respir J 1991; 5: 115-121.

73. Boschetto P, Fabbri LM, Zocca E, et al. Prednisone inhibits late asthmatic reactions and airway inflammation induced by toluene diisocyanate in sensitized subjects, J Allergy Clin Immunol 1987; 80: 261-267.

74. Chan-Yeung M, Chan H, Tse KS, Salari H, Lam S. Histamine and leukotriene release in bronchoalveolar lavage fluid during plicatic acid-induced bronchoconstriction. J Allergy Clin Immunol 1989; 84: 762-768.

75. Zocca E, Fabbri LM, Boschetto P, et al. Leukotriene $\mathrm{B}_{4}$ and late asthmatic reactions induced by toluene diiscocyanate. J Appl Physiol 1990; 68: 1576-1589.

76. Persson CGA. Mucosal exudation mechanisms. ACI News 1991; 35: 142-148.

77. Perrson CGA. Plasma exudation and asthma. Lung 1988; 166: 1-23.

78. Persson CGA. Role of plasma exudation in asthmatic airways. Lancet 1986; ii: 1126-1129.

79. Persson XGA. Leakage of macromolecules from the traceobronchial microcirculation. Am Rev Respir Dis 1987; 135 (Suppl.): 71-75.

80. Fabbri LM, Danieli D, Crescioli S, et al. Fatal asthma in a subject sensitized to toluene diisocyanate. Am Rev Respir Dis 1988; 137: 1494-1498.

81. Macklem PT. Mechanical factors determining bronchoconstriction. 1989; 2 (Suppl. 6): 516-519.

82. Holtzman MJ, Ferdman B, Bohrer A, Turk J. Synthesis of the 1-0-hexadecyl molecular species of plateletactivating factor by airway epithelial and vascular endothelial cells. Biochem Biophys Res Commum 1992; 171: 357-364.

83. Laitinen LA, Heino M, Laitinen A, Kava T, Haahtela T. Damage of the airway epithelium and bronchial reactivity in patients with asthma. Am Rev Respir Dis 1985; 131: 599-606.
84. Saetta M, Fabbri LM, Danieli D, Picotti G, Allegra L. Pathology of bronchial asthma and animal models of asthma. Eur Respir J 1989; 2 (Suppl. 6): 477-482.

85. Saetta M, Di Stefano A, Maestrelli P, et al. Activated T-lymphocytes and macrophages in bronchial mucosa of subjects with chronic bronchitis. Am Rev Respir Dis 1993; 147: 301-306.

86. Beasley R, Roche WR, Roberts JA, Holgate ST. Cellular events in the bronchi in mild asthma and after bronchial provocation. Am Rev Respir Dis 1989; 139: 806-817.

87. Saetta M, Maestrelli P, Di Stefano A, et al. Effect of cessation of exposure to toluene diisocyanate (TDI) in bronchial mucosa of subjects with TDI-induced asthma. Am Rev Respir Dis 1992; 145: 169-174.

88. Di Stefano A, Maestrelli P, Mapp CE, Fabbri LM, Saetta M. The reduction of airway subepithelial fibrosis after cessation of exposure to toluene diisocyanate (TDI) in sensitized subjects is associated with a reduction of mast cells and fibroblasts. Am Rev Respir Dis 1993; 147: A557.

89. Di Stefano A, Saetta M, Maestrelli P, et al. Mast cells in airway mucosa and rapid development of occupational asthma induced by toluene diisocyanate. Am Rev Respir Dis 1993; 147: 1005-1009.

90. Frew AJ, Chan H, Lam S, Chan-Yeung M. Bronchial inflammation in occupational asthma due to western red cedar. Am J Resp Crit Care Med 1994; (in press).

91. Marsh DG, Bias WB, Ishizaka K. Genetic control of basal serum immunoglobulin E level and its effect on specific reaginic sensitivity. Proc Natl Acad Sci 1974; 71: 3588-3592

92. Rao DC, Lalovel JM, Morton NE, Gerrard JW. Immunoglobulin E revisited. Am J Hum Genet 1980; 32(A): 620-625.

93. Marsh DG, Holgate SJ, Lochart A, In: The Genetics of Asthma. Oxford, Blackwell Scientific Publ., 1993.

94. Bignon JS, Aron Y, Ju LY, et al. HLA class II alleles in isocyanate-induced asthma. Am J Resp Crit Care 1994; (in press).

95. Sasazuki T. HLA-linked immune suppression genes. Jpn J Human Genet 1990; 35: 1-13.

96. Marsh DG. Immunogenetic and immunochemical factors determining immune responsiveness to allergens: studies in unrelated subjects. In: Marsh DG, Blumenthal MN, eds. Genetic and Environmental Factors in Clinical Allergy. Minneapolis, University of Minnesota Press, 1990; 97: 123.

97. Marsh DG, Meyers DA, Bias WB. The epidemiology and genetics of atopic allergy. $N$ Engl J Med (Med Progr Series) 1981; 305: 1551-1559.

98. Reid MJ, Nish WA, Wishman BaA, et al. HLA DR4associated nonresponsiveness in mountain cedar allergen. J Allergy Clin Immunol 1992; 89: 593-598.

99. Davies RJ, Butcher BT, O’Neil CE, Salvaggio JE. The in vitro effect of toluene diisocyanate on lymphocyte cyclic adenosine monophosphate production by isoproterenol, prostagalandin and histamine: a possible mode of action. J Allergy Clin Immunol 1977; 60: 223-229.

100. Chan-Yeung M. Immunologic and nonimmunologic mechanisms in asthma due to Western red cedar (Thuja plicata). J Allergy Clin Immunol. 1982; 70: 32-37.

101. Barnes PJ, Braniuk JN, Belvisi MG. Neuropeptides in the respiratory tract. Part II. Am Rev Respir Dis 1991; 144: 1391-1399.

102. Ollerenshaw SL, Jarvis D, Woolcock AJ, Sullivan CE, Scheibner T. Absence of immunoreactive vasoactive intestinal polypeptide in tissue from the lungs of patients with asthma. N Engl J Med 1989; 320: 1244-1248. 
103. Ollerenshaw SL, Jarvis D, Sullivan CE, Woolcock AJ. Substance $\mathrm{P}$ immunoreactive nerves in airways from asthmatics and nonasthmatics. Eur Respir J 1991; 4: 673-682.

104. Greiff L, Erjfalt I, Wollmer P, et al. Nicotine evokes neurogenic mucosal exudation of plasma into guineapig but not into human airways. Thesis, Lund, 1990; pp. 89-101.

105. Stanisz A, Scicchitano R, Stead R, et al. Neuropeptides and immunity. Am Rev Respir Dis 987; 136: S48S51.

106. Nadel JA. Neutral endopeptides modulates neurogenic inflammation. Eur Respir J 1991; 4: 745-754.

107. Mapp CE, Chitano P, Fabbri LM, et al. Evidence that toluene diisocyanate (TDI) activates the efferent function of capsaicin-sensitive primary afferents. Eur J Pharmacol 1990; 180: 113-118.

108. Mapp CE, Chitano P, Fabbri LM, et al. Pharmacological modulation of the contractile response to toluene diisocyanate in the rate urinary bladder. $\mathrm{Br} J$ Pharmacol 1990; 100: 886-888.

109. Mapp CE, Graf PD, Boniotti A, Nadel JA. Toluene diisocyanate contracts guinea-pig bronchial smooth muscle by activating capsaicin-sensitive sensory nerves. J Pharmacol Exp Ther 1991; 256: 1082-1085.

110. Sheppard D, Thompson JE, Scypinski L, et al. Toluene diisocyanate increases airway responsiveness to substance $\mathrm{P}$ and decreases airway enkephalinase. J Clin Invest 1988: 81: 1111-1115.

111. Mapp CE, Boniotti A, Papi A, et al. The effect of phosphoramidon and epithelium removal on toluene diisocyanate-induced contractions in guinea-pig bronchi. Eur Respir J 1992; 5: 331-333.

112. Mapp CE, Boniotti A, Graf PD, et al. Bronchial smooth muscle responses evoked by toluene diisocyanate are inhibited by ruthenium red and by indomethacin. Eur $J$ Pharmacol 1991; 200: 73-76.

113. Mapp CE, Boniotti A, Masiero M, et al. Toluene diisocyanate-stimulated release of arachidonic acid metabolites in the organ bath of isolated guinea-pig airways. Eur J Pharmacol (Environ Toxicol Pharmacol Section) 1993; 248: 277-280.

114. Mapp CE, Boniotti A, Papi A, et al. The effect of compound $48 / 80$ on contractions induced by toluene diisocyanate in isolated guinea-pig bronchus. Eur J Pharmacol (Environ Toxicol Pharmacol Section) 1993; 248: 67-73. 